Jp.jok (Jurnal Pendidikan Jasmani, Olahraga dan Kesehatan)

http://ejurnal.budiutomomalang.ac.id/index.php/jpjok

Doi : $\underline{\text { https://doi.org/10.33503/jp.jok.v5i1.1448 }}$

\title{
Adaptation of The New Normal Sports Training Centering System
}

\author{
Prayogi Dwina Angga ${ }^{1)}$, Deddy Whinata Kardiyanto ${ }^{2)}$ \\ Program Studi Pendidikan Guru Sekolah Dasar \\ Fakultas Keguruan dan Ilmu Pendidikan \\ ${ }^{1}$ Universitas Mataram, Indonesia \\ ${ }^{2}$ Universitas Sebelas Maret, Indonesia \\ Email: 1prayogi.angga@unram.ac.id, ${ }^{2}$ deddywhinata84@gmail.com
}

\begin{abstract}
The COVID-19 pandemic has resulted in the temporary suspension of the training centering system which has resulted in complex decisions relating to the continuation of training activities in accordance with existing circumstances. This paper aims to provide education and guidance in the implementation of regular exercise programs that must be realized as a solution to minimize the occurrence of COVID-19 transmission in the regular training process as well as provide understanding to the main sports branch management, coaches and athletes in carrying out regular training programs. This study uses a literature review method where the researcher conducts a series of studies by reviewing and analyzing various content and data, which involves various kinds of information related to the implementation of the training centering system in the new normal era. There are 4 key principles in the re-implementation of the training process on a regular basis or training camps, including preparation for resumption of training, criteria for training commencement, assessments and guidelines that serve as a reference for the implementation of training camps, as well as management and strategies for mitigating COVID-19 risks at training camps.
\end{abstract}

Keywords: Adaptation, Sport, New Normal

\section{Adaptasi Sistem Pemusatan Latihan Olahraga Era New Normal}

\begin{abstract}
ABSTRAK
Pandemi COVID-19 menyebabkan pengentian sementara sistem pemusatan latihan yang berdampak pada keputusan kompleks yang berhubungan dengan kelanjutan kegiatan latihan sesuai dengan keadaan yang ada. Tulisan ini bertujuan memberikan edukasi dan panduan dalam pelaksanaan program latihan regular harus diwujudkan sebagai solusi untuk meminimalisir terjadinya penularan COVID-19 dalam proses pelatihan regular serta memberikan pemahaman kepada pengurus induk cabang olahraga, pelatih dan atlet dalam melaksanakan program latihan regular. Penelitian ini menggunakan metode kajian literatur dimana peneliti melakukan serangkaian penelitian dengan mengkaji dan menganalisis berbagai konten dan data, yang melibatkan berbagai macam informasi yang berhubungan dengan pelaksanaan sistem pemusatan latihan pada era new normal. Terdapat 4 prins ip yang menjadi kunci dalam pelaksanaan kembali proses pelatihan secara reguler atau pemusatan latihan daiantaranya, persiapan dimulai kembali pelatihan, kriteria dimulainya pelatihan, penilaian dan panduan yang menjadi acuan pelaksanaan pemusatan latihan, serta manajemen dan strategi mitigasi resiko COVID-19 pada pemusatan latihan.
\end{abstract}

Kata Kunci: Adaptasi, Olahraga, New Normal

Info Artikel

Dikirim

Diterima

Dipublikasikan : 30 November 2021
(C) 2021 IKIP BUDI UTOMOMALANG

P-ISSN 2613-9421

E-ISSN 2654-8003

\footnotetext{
Alamat korespondensi: pravogi.angga@unram.ac.id

Universitas Mataram J1. Majapahit No.62, Gomong, Kec. Selaparang, Kota Mataram, Nusa Tenggara Barat. 83115, Indonesia
} 
12 Prayogi Dwina Angga ${ }^{1)}$, Deddy Whinata Kardiyanto ${ }^{2)}$ Jp.jok (Jurnal Pendidikan. Jasmani, Olahraga dan Kesehatan). 5(1) $11-25$

\section{PENDAHULUAN}

Corona virus 2019 (COVID-19) saat ini menjadi pandemi pernafasan sangat menular dan fatal yang memiliki dampak buruk dan sangat besar pada berbagai aspek kehidupan di masyarakat, salah satunya olahraga. Event dan kegiatan olahraga dianggap bisa menjadi salah satu media penyebaran COVID-19 yang sangat cepat. Bahkan event tertinggi pada olahraga yaitu Olimpiade yang sedianya diadakan di Tokyo tahun 2020 dengan sangat terpaksa harus ditunda dan dibatalkan pelaksanaannya (Gallego dkk., 2020; Gautret dkk., 2020), sebagai upaya untuk membatasi penyebaran virus dengan menghindari adanya keramaian (Nurfajriani, 2020). Selain itu, multievent olahraga Nasional seperti Pekan Olahraga Nasional (PON) ke-20 yang akan dige lar di Papua juga terpaksa ditunda (Humas Sekretariat Kabinet Republik Indonesia, 2020), tidak terkecuali beberapa agenda event olahraga lainnya juga terpaksa dibatalkan. Sejumlah kasus hasil positif COVID-19 terhadap atlet profesional di tingkat global dan liga utama menjadi bukti bahwa tidak ada seorang pun yang aman di masa pandemi ini (Corsini dkk., 2020; Al-Qodariah, 2020).

Pembatalan multievent olahraga serta ajuran untuk menjaga jarak sebagai upaya pencegahan penularan virus COVID-19 berdampak negatif pada organisasi olahraga dan atlet sehingga mereka tidak dapat melanjutkan program pelatihan regular (Kardiyanto, 2020; World Health Organization, 2020). Atlet mengalami pengurangan yang signifikan dalam frekuensi pelatihan dan waktu yang dihabiskan untuk menyelesaikan berbagai aktivitas terkait pelatihan (Jagim dkk., 2020), akibat kondisi pelatihan yang tidak memadai (Chen dkk., 2020). Sangat jelas bahwa kondisi tersebut berdampak besar pada sistem fisiologis termasuk peningkatan kandungan lemak tubuh dan penurunan masa otot, penurunan kekebalan tubuh, menurunnya ketajaman dan ketangguhan mental, insomnia dan depresi (Chen dkk., 2020; Halabchi dkk., 2020). Konsekuensi nyatanya adalah dampak negatif baik jangka pendek maupun jangka panjang pada kebugaran fisik dan ke mampuan kompetitif atlet. Walaupun masih sulit untuk memprediksi durasi krisis global COVID-19 yang saat ini sedang berlangsung, namun dalam hal memprediksi hilangnya adaptasi yang dipicu oleh pelatihan masih sangat 
dimungkinkan (Melchiorri dkk., 2014; Mujika \& Padilla, 2001; RodríguezFernández dkk., 2018).

Adanya pandemi COVID-19 menyebabkan penghentian sementara sistem pemusatan latihan olahraga, dan latihan mandiri pun menjadi pilihan utama bagi atlet. Atlet dihadapkan pada keputusan yang kompleks mengenai kelanjutan kegiatan pelatihan sesuai dengan keadaan saat ini. Hal tersebut akan berdampak secara signifikan pada fisik dan mental atlet termasuk penurunan kondisi fis ik, perubahan pola tidur, nutrisi yang memburuk serta perasaan depresi (Fabre dkk., 2020; Latella \& Haff, 2020). Oleh karena itu, upaya menyeimbangkan faktor resiko penurunan kondisi fisik dengan faktor resiko infeksi atau penularan menjadi pertimbangan utama dalam memulai kembali aktivitas pelatihan secara normal pada masa pandemi (Wong dkk., 2020). Agar menjaga performanya, atlet harus tetap menjalani program latihan regular dengan aman pada lingkungan COVID-19. Untuk itu perlu adanya standar minimum yang harus dipenuhi organisasi olahraga sebelum dimulainya kembali pelatihan regular dan kompetisi (Carmody dkk., 2020; Huyghe dkk., 2020).

Upaya yang menerapkan kembali program latihan pada era baru harus dibarengi dengan analisis situasi dan managerial yang baik dari organisasi olahraga sebagai operator teknis penye lenggara pemusatan latihan. Penyelenggara pemusatan latihan harus mempertimbangkan tindakan pengendalian infeksi bawaan dari evaluasi risiko-manfaat dan sumber daya yang tersedia. Hal tersebut menjadi dasar agar sistem yang telah dibangun dapat diadaptasikan pada program pelatihan di era new normal. Alur sistem yang dibangun setelah new normal harus dievaluasi dan diputuskan berdasarkan kasus per kasus, dengan menyeimbangkan manfaat, risiko, dan opsi mitigasi risiko, yang mungkin terpengaruh oleh berbagai aspek pasca pandemi yang rusak, salah satunya pada program pemusatan latihan yang telah dirancang.

Sangat jelas sampai saat ini masih belum adanya panduan yang dapat menjadi guidance atau petunjuk yang dapat memberikan arah tentang pelaksanaan sistem pemusatan latihan dalam kondisi pandemi COVID-19. Tidak adanya panduan penyiapan latihan atlet pada era new normal membuat hal ini menjadi permasalahan mendesak dan perlu ada solusi yang tepat. Upaya edukasi dan 
14 Prayogi Dwina Angga ${ }^{1)}$, Deddy Whinata Kardiyanto ${ }^{2)}$ Jp.jok (Jurnal Pendidikan. Jasmani, Olahraga dan Kesehatan). 5(1) $11-25$

penyusunan panduan yang diadaptasi dari berbagai panduan yang te lah ada dalam pelaksanaan program latihan regular harus diwujudkan sebagai solusi untuk meminimalisir terjadinya penularan COVID-19 dalam proses pelatihan regular serta memberikan pemahaman kepada pengurus induk cabang olahraga, pelatih dan atlet dalam melaksanakan program latihan regular. Dengan adanya panduan bagaimana sistem adaptasi yang dapat dilakukan pada pelaksanaan program latihan era new normal maka akan memberikan jaminan yang aman terhadap proses pelaksanaan program latihan reguler, seluruh stakeholder yang terlibat dalam proses pelatihan dapat memanfaatkan hasil kajian ini sebagai panduan minimal dalam pelaksanaan sistem pemusatan latihan.

\section{METODE}

Penelitian ini menggunakan metode kajian literatur dimana peneliti melakukan serangkaian penelitian dengan mengkaji dan mengana lis is berbagai konten dan data, yang melibatkan berbagai macam informasi yang berhubungan dengan pelaksanaan sistem pemusatan latihan pada era new normal. Data dikumpulkan dari berbagai sumber yang relevan yang berasal dari berbagai artikel, seperti buku, ensiklopedi, dokumen, dan sebaga inya dengan tujuan untuk menemukan berbagai macam teori dan gagasan yang kemudian dapat dirumuskan hasil sesuai dengan tujuan penelitian. Literatur yang dibutuhkan sebagai bahan kajian dalam penelitian ini dihadirkan secara online melalui mesin cari (search engine) yaitu Google Scholar dan ScienceDirect yang kemudian akan diklasifikasikan secara langsung dengan melibatkan Query (Nasution, 2017). Query ini adalah permintaan informasi atau pertanyaan tertentu dari sebuah data base yang ditulis dalam format tertentu yang memungkinkan peneliti membentuk sekumpulan akuisisi data, langkah-langkah pemfilteran dan transformasi untuk persyaratan analisis data penelitian.

\section{HASIL DAN PEMBAHASAN}

Berdasarkan hasil pencarian terhadap kesesuaian artikel dengan pokok bahasan kajian, maka diperoleh 6 dokumen dalam bentuk artikel serta dokumen kebijakan dengan judul sebagai berikut: (1) 5 Dimensions Of Covid-19 Policy Impact 
On The National Sports System (Gunawan, 2020); (2) TEAM to Defeat COVID-19 A Management Strategy Plan to Address Return to Play in Sports Medicine (SantosFerreira dkk., 2020); (3) COVID-19 Return to High Performance Sport Framework (Own The Podium, 2020); (4) The Australian Institute of Sport framework for rebooting sport in a COVID-19 environment (Hughes dkk., 2020); (5) COVID-19 Epidemic: Exercise or Not to Exercise; That is the Question! (Halabchi dkk., 2020); (6) When can professional sport recommence safely during the COVID-19 pandemic? Risk assessment and factors to consider (Carmody dkk., 2020). Selanjutnya artikel dan dokumen tersebut dianalisis dan dikaji lebih lanjut untuk menemukan formulasi yang tepat untuk menjawab tujuan penelitian.

Kajian ini diawali dari srtikel yang berjudul "5 Dimensi Dampak Kebijakan COVID-19 terhadap Sistem Keolahragaan Nasional" yang memberikan gambaran yang jelas mengenai bagaimana dampak COVID-19 terhadap kondisi keolahragaan nasional yang diulas secara menyeluruh sebagai bahan pertimbangan pemangku kebijakan di Indonesia. Hasil analisa dengan menggunakan pendekatan kebijakan publik dari Thomas R. Dye (1972) memunculkan kerangka pikir dampak COVID-19 pada keolahragaan nasional sebagai berikut (Gunawan, 2020).

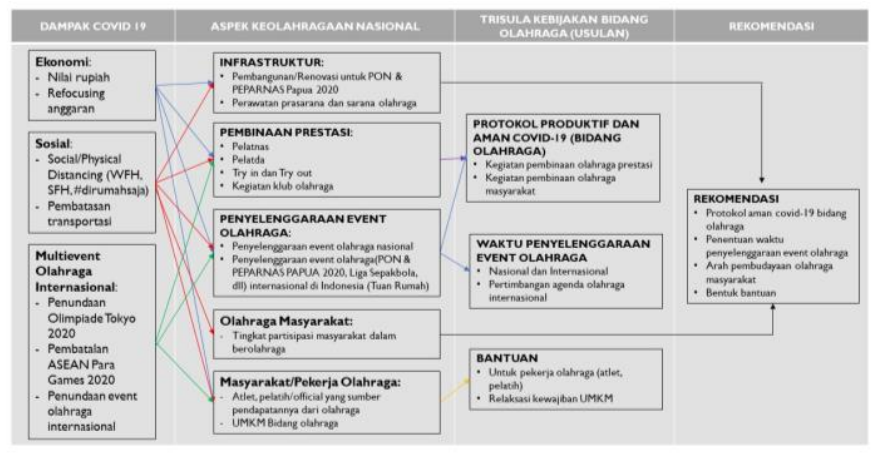

Gambar 1. Bagan Analisis Dampak COVID-19 terhadap Keolahragaan Nasional

Berdasarkan bagan analisis dampak COVID-19 terhadap Keolahragaan Nasional dapat dicermati bahwa pandemi COVID-19 menyebabkan berbagai pembatasan yang berkibat pada penundaan berbagai event olahraga baik dalam skala nasional maupun internasional. Adanya pembatasan sosial atau bahkan lockdown menyebabkan proses pembinaan prestasi yang terganggu, khususnya 
16 Prayogi Dwina Angga ${ }^{1)}$, Deddy Whinata Kardiyanto ${ }^{2}$ Jp.jok (Jurnal Pendidikan. Jasmani, Olahraga dan Kesehatan). 5(1) $11-25$

dalam penyelenggaraan pemusatan latihan, baik Pelatda maupun Pelatnas bahkan Pemusatan Latihan Olahraga Pelajar (PPLP). Salah satu usulan penting dari kajian tersebut adalah bagaimana menerapkan protokol yang aman dalam penyelenggaraan pemusatan latihan olahraga.

Apabila mengacu kepada surat edaran yang telah dikeluarkan oleh Kemenpora, maka seharusnya program pelatihan regular atau pemusatan latihan dalam bentuk Pelatnas/Pelatda/Pelatprov/Pelatkot bisa dilakukan dengan berbagai ketentuan yang telah diatur (Satuan Tugas Penanganan COVID-19, 2020). Salah satunya adalah penerapan protokol pencegahan COVID-19 yang ketat dan melakukan tes PCR bagi seluruh personil yang terlibat proses pelatihan pada cabang olahraga individu. Namun mekanisme teknis dan detail mengenai tata laksana tentang bagaimana persiapan latihan, pelaksanaan latihan hingga mitigasi kasus dugaan atau bahkan yang terkonfirmasi positif COVID-19 masih belum diatur secara detail. Selain itu, masih minimnya pengetahuan pengurus KONI, pengurus induk organisasi cabang olahraga, pelatih dan atlet juga menjadi permasalahan lainnya dalam menerapkan ke mbali pemusatan latihan atau program latihan regular dalam tatanan normal baru.

Perlahan namun pasti, para pengurus cabang olahraga dan atlet kembali untuk melakukan penyesuaian pelatihan. Sistem pemusatan latihan masih menjadi pilihan yang dianggap paling tepat dan paling efektif apabila dibandingkan dengan latihan mandiri (Nahari \& Faruk, 2021). Adaptasi sistem latihan olahraga era new normal memberikan standar dasar yang paling minimal untuk dipenuhi oleh organisasi olahraga dalam memulai kembali pemusatan latihan atau program pelatihan regular bagi atlet dan ketentuan yang harus dipenuhi oleh komponen yang terlibat didalamnya (Firdaus \& Pudjijuniarto, 2021). Standar dasar yang dikembangkan berdasarkan bukti terbaik yang tersedia guna memastikan keselamatan atlet dan personel lainnya dalam konteks yang lebih luas. Untuk mengurangi risiko penularan COVID-19, edukasi dan informasi kepada seluruh unsur yang terlibat dalam proses pelatihan regular tentang strategi mitigasi risiko menjadi sangat penting. Tidak boleh dianggap bahwa atlet dan personel lain memiliki pemahaman yang akurat tentang risiko kesehatan. Edukasi dan informasi akan membantu untuk mempromosikan serta menetapkan harapan untuk perilaku 
yang diperlukan sebelum memulai kembali kegiatan latihan reguler. Berikut adalah kerangka gambaran pelaksanaan pemusatan latihan atau kegiatan latihan regular di lingkungan COVID-19 (Hughes dkk., 2020).

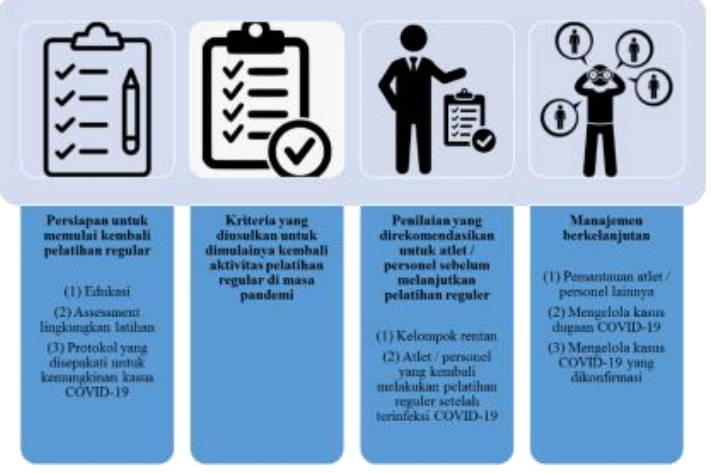

Gambar 2. Kerangka untuk Memulai Kembali Pelatihan Olahraga Secara Reguler di Lingkungan COVID-19 (Hughes dkk., 2020)

Kembalinya aktivitas pemusatan latihan atau program pelatihan regular harus mengikuti kebijakan dan arahan dari otoritas tertinggi yang menangani COVID-19, dalam hal ini adalah Satuan Tugas Penanganan COVID-19. Namun, perlu diperhatikan bahwa masing-masing daerah atau provinsi dapat mengizinkan mulainya kembali beberapa kegiatan olahraga seperti pemusatan latihan pada waktu yang berbeda, semuanya tergantung pada transmisi lokal COVID-19 yang terdapat pada daerah tersebut, sumber daya, dan beberapa variabel lain yang dapat mempengaruhi kebijakan lokal dalam memulai kegiatan pemusatan latihan atau pelatihan regular. Bahkan dalam satu provinsi atau wilayah dapat terjadi variabilitas geografis, sehingga relaksasi/peningkatan pembatasan mungkin diperlukan dalam merespon jumlah kasus COVID-19 yang berfluktuasi. Dimulainya kembali aktivitas olahraga dapat dilakukan secara tidak linear dan harus dipandu otoritas kesehatan atau satuan tugas penanganan COVID-19 lokal atau provinsi. Sebelum memulai pemusatan latihan atau kegiatan pelatihan regular terdapat beberapa faktor yang mesti diperhatikan, diantaranya: (1) penurunan jumlah penularan kasus COVID-19 yang berkesinambungan; (2) kapasitas sistem perawatan kesehatan yang memadai; (3) organisasi olahraga, atau pengurus olahraga sebagai administrator pe laksana harus membuat penilaian risiko terhadap pemusatan latihan dengan panduan otoritas kesehatan atau satuan tugas penanganan COVID-19 setempat (Own The Podium, 2020). Dengan demikian 
18 Prayogi Dwina Angga ${ }^{1)}$, Deddy Whinata Kardiyanto ${ }^{2}$ Jp.jok (Jurnal Pendidikan. Jasmani, Olahraga dan Kesehatan). 5(1) $11-25$

maka organisasi atau pengurus cabang olahraga dapat bertanggung jawab secara penuh terhadap mitigasi risiko COVID-19, strategi mitigasi yang digunakan serta seluruh informasi yang berkaitan dengan pelaksanaan pemusatan latihan.

Apabila mengacu pada kerangka kembalinya aktivitas olahraga prestasi di lingkungan COVID-19 yang dilakukan oleh Kanada (Own The Podium, 2020), maka terdapat 4 prinsip dasar yang menjadi kunci pelaksanaannya, diantaranya: (1) Prinsip utama (main principle), menguraikan kajian yang logis dan metodis dalam pelaksanaan kembalinya aktivitas olahraga prestasi, salah satunya dalah pemusatan latihan dengan mengacu kepada pedoman otoritas kesehatan masyarakat; (2) Alat penila ian resiko COVID-19 untuk olahraga, alat ini berfungsi sebagai a lat fungsional untuk menilai tingkat resiko penularan COVID-19 dalam lingkungan pelatihan dan dampak dari startegi mitigasi potensial; (3) Pedoman Umum Kembali ke Olahraga, memberikan pedoman umum yang diratifikasi dari pedoman WHO tentang " WHO Guidelines for Mass Gatherings" dan mendukung pengembangan strategi mitigasi risiko khusus olahraga (WHO, 2021); (4) Panduan Kembalinya Aktivitas Khusus Olahraga, panduan ini disusun berdasarkan konteks dan risiko olahraga, lingkungan dan berfokus pada strategi menjaga jarak, komposisi dan jumlah komponen yangterlibat dlam proses pelatihan, serta akses dan adaptasi fasilitas dan peralatan. Secara jelas, kerangka pelaksanaan olahraga prestasi dalam konteks COVID-19 tergambar sebagai berikut.

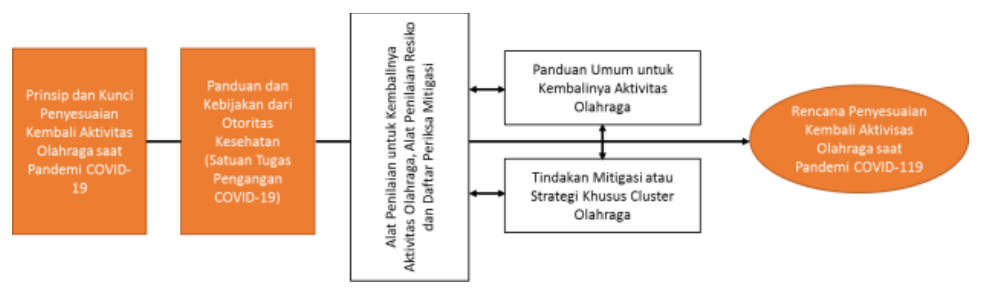

Gambar 3. Kerangka Pelaksanaan Aktivitas Olahraga saat Pandemi COVID-19

Sebelum memulai kembali aktivitas pelatihan reguler, organisasi olahraga (KONI dan pengurus cabang olahraga) harus mulai mempersiapkan atlet, personel lain (pelatih, ofisial, dan staf pendukung lainnya), dan lingkungan tempat latihan yang aman dengan petunjuk yang jelas. Penilaian risiko yang menyeluruh harus dilakukan. Pelatihan reguler tidak boleh dilanjutkan sampai langkah-langkah yang 
tepat diterapkan. Tindakan yang diperlukan akan spesifik untuk masing-masing cabang olahraga sesuai dengan karakteristiknya baik itu yang individu mapun kelompok dan juga lingkungan pelatihannya. Untuk itu, penyusunan pedoman yang disertai edukasi mengenai penyiapan atlet untuk dapat kembali ke latihan regular menjadi penting guna mewujudkan rasa aman dan menjaga keselamatan seluruh unsur yang terlibat dalam proses latihan.

Pengkondisian lingkungan atau tempat latihan menjadi salah satu bagian yang harus diperhatikan, hal ini dilakukan agar meminimalisir transmisi atau penularan COVID-19 saat proses pelatihan sehingga memunculkan klaster baru. Menyediakan fasilitas cuci tangan adalah kewajiban yang harus dilakukan oleh pelaksana atau pengelola tempat latihan, dan siapapun yang mengikuti proses latihan wajib mencuci tangan sebelum mereka memasuki area latihan. Penilaian terhadap jenis olahraga dan area yang digunakan (indoor atau outdoor) menjadi pertimbangan utama dalam mengatur mekanisme gelaran latihan. Pelaksanaan latihan olahraga di dalam ruangan harus menggunakan protokol yang lebih ketat mengingat beberapa hasil studi menyebutkan bahwa transmisi COVID-19 di dalam ruangan lebih tinggi apabila dibandingkan dengan di luar ruangan (Habeebullah dkk., 2021; Noorimotlagh dkk., 2021).

Jumlah komponen yang terlibat dalam hal ini atlet saat melakukan kegiatan latihan juga menjadi pertimbangan mengingat rasio area latihan dan jumlah atlet harus diminimalkan, karena menjaga jarak ketika latihan tetap menjadi kunci dalam menjaga penularan COVID-19. Mengatur jadwal latihan dengan menerapkan beberapa sesi untuk atlet yang akan berlatih dengan menggunakan fasilitas yang sama juga menjadi salah satu strategi yang dinilai aman dan efektif dalam pelaksanaan pemusatan latihan (Santos-Ferreira dkk., 2020). Hal ini tentunya akan mengurangi jumlah atlet yang berinteraksi secara bersamaan dalam satu sesi latihan. Pembersihan area latihan, terutama fasilitas yang digunakan secara bersama harus dilakukan secara teratur dan rutin dengan cara desinfeksi.

Kembalinya proses pelatihan regular dalam bentuk pemusatan latihan tentunya bulkan resiko penularan atau terjadinya cluster baru COVID-19, baik itu gejala suspek atau memang yang positif terinfeksi COVID-19. Untuk itu dalam pelaksanaannya perlu kesepakatan atau aturan yang jelas mengenai protokol yang 
disepakati ketika terjadi kasus suspek atau positif COVID-19. Beberapa gejala tertentu dan indeks kecurigaan yang tinggi terhadap COVID-19 (HSC Public Health Agency, 2020; World Health Organization, 2021) harus menjadi kewaspadaan pada setiap sumber daya yang terlibat pada sistem pemusatan latihan, diantaranya batuk yang terus menerus, suhu tinggi, perubahan pada penciuman dan perasa, serta gejala lain termasuk diare (Song dkk., 2020). Tindakan yang dapat dilakukan guna mengurangi dampak resiko penularan COVID-19 pada sumber daya yang terlibat dalam pelatihan regular atau pemusatan latihan, yaitu: melakukan penilaian resiko COVID-19 pada pelaksanaan pemusatan latihan atau pelatihan regular (Carmody dkk., 2020), membuat protokol dan rencana tidakan atau mitigasi COVID-19, me mbuat area isolasi khusus bagi mereka yang diduga memiliki gejala COVID-19, skrining seluruh sumber daya yang mengikuti pelaksanaan proses pemusatan latihan sehingga dapat mencegah hadir ketika tidak sehat, membuat catatan kehadiran selama 21 hari untuk memfasilitasi pelacakan kontak, serta mengembangkan aplikasi pelacakan atau tracing lokal.

Apabila ada sumber daya (atlet, pelatih, of isial, pengurus) yang terlibat pada pemusatan latihan datang ke tempat latihan dengan dugaan COVID-19 maka beberapa tindakan yang harus diambil yaitu, memerintahkan agar segera mengenakan masker, memintanya untuk segera meninggalkan tenpat latihan, atau jika tidak dapat meninggalkan tempat latihan maka pindahkan ke tempat isolasi yang telah disediakan dengan meminimalisir personel yang mengakses ruangan isolasi, membersihkan area yang terkena dampak akibat kontak fisik dengan atlet yang diduga memiliki gejala atau positif COVID-19, serta melanjutkan sesi latihan apabila tidak ada masalah lain yang relevan atau tidak ada personel yang sakit.

Semua kasus positif harus diinformasikan ke dinas kesehatan atau satuan tugas penanganan COVID-19 setempat, dan penyelenggara pemusatan latihan sebagai administrator harus berkoordinasi dengan dinas kesehatan atau satuan tugas penganan COVID-19 untuk melakukan tracing atau pelacakan terhadap siapapun yang kontak serta meninjau perlunya menghentikan sementara kegiatan pemusatan latihan atau pelatihan regular, tergantung pada jumlah kasus positif di 
tempat olahraga tertentu. Semua kasus positif COVID-19 pada atlet harus mengikuti pedoman kembali ke olahraga untuk COVID-19 (Elliott dkk., 2020). Bagi mereka yang diduga memiliki gejala COVID-19 dan telah melakukan tes swab COVID-19 dengan hasil ne gatif, mereka dapat kembali berolahraga 48 jam setelah tidak menunjukkan gejala.

Upaya yang menerapkan kembali program latihan atau pemusatan latihan pada era baru harus dibarengi dengan analisis situasi dan managerial yang baik dari organisasi olahraga dalam hal ini sebagai administrator atau pelaksana harus mempertimbangkan tindakan pengendalian infeksi bawaan dari evaluasi risikomanfaat dan sumber daya yang tersedia. Hal tersebut menjadi dasar agar sistem yang telah dibangun dapat diadaptasikan pada program pelatihan di era new normal. Alur sistem yang dibangun setelah new normal harus dievaluasi dan diputuskan berdasarkan kasus per kasus, de ngan menyeimbangkan manfaat, risiko, dan opsi mitigasi risiko, yang mungkin terpengaruh oleh berbagai aspek pasca pandemi yang rusak, salah satunya pada program pemusatan latihan yang telah dirancang.

\section{SIMPULAN}

Olahraga profesional, serta dimulainya kembali, menjadi perhatian sekunder dalam konteks pandemi COVID-19 secara global. Adaptasi sistem pemusatan latihan ini dapat menjadi panduan yang tepat dalam mengoptimalkan proses pemusatan latihan atau pelatihan reguler dengan memprioritaskan keselamatan seluruh sumber daya yang terlibat. Terdapat 4 prinsip yang menjadi kunci dalam pelaksanaan kembali proses pelatihan secara reguler atau pemusatan latihan daiantaranya, persiapan dimulai kembali pelatihan, kriteria dimulainya pelatihan, penilaian dan panduan yang menjadi acuan pelaksanaan pemusatan latihan, serta manajemen dan strategi mitigasi resiko COVID-19 pada pemusatan latihan.

Hasil kajian ini masih memiliki keterbatasan yang berhubungan dengan pengupulan artikel secara komprehens if dengan memanfaatkan berbagai database atau search engine secara lebih lengkap, namun secara umum hasil yang diperoleh telah dapat menjawab permasalahan utama sehingga hasil kajian ini dapat me njadi dasar operasional dalam pe laksanaan pemusatan latihan di era new normal. Untuk 
22 Prayogi Dwina Angga ${ }^{1)}$, Deddy Whinata Kardiyanto ${ }^{2)}$ Jp.jok (Jurnal Pendidikan. Jasmani, Olahraga dan Kesehatan). 5(1) $11-25$

itu pada masa mendatang diharapkan ada regulasi serta petunjuk yang jelas sebagai panduan untuk pelaksanaan pemusatan latihan di berbagai tingkatan.

\section{DAFTAR RUJUKAN}

Al-Qodariah, F. (2020, Oktober 16). 13 Atlet Dunia yang Positif COVID-19: Ketika Olahragawan Ikut Kena Corona, dari Rossi hingga Ronaldo. Pikiran-Rakyat.com. https //www.pikiran-rakyat.com/olahraga/pr01837484/13-atlet-dunia-yang-positif-covid-19-ketika-olahragawan-ikutkena-corona-dari-rossi-hingga-ronaldo

Carmody, S., Murray, A., Borodina, M., Gouttebarge, V., \& Massey, A. (2020). When can professional sport recommence safely during the COVID-19 pandemic? Risk assessment and factors to consider. British Journal of Sports Medicine, 54(16), 946-948. https://doi. org/10.1136/bjsports-2020102539

Chen, A. T., Ryskina, K. L., \& Jung, H.-Y. (2020). Long-Term Care, Residential Facilities, and COVID-19: An Overview of Federal and State Policy Responses. Joumal of the American Medical Directors Association. https://doi.org/10.1016/j.jamda.2020.07.001

Corsini, A., B isc iotti, G. N., Eira le, C., \& Volpi, P. (2020). Football cannot restart soon during the COVID-19 emergency! A critical perspective from the Italian experience and a call for action. British Journal of Sports Medicine, 54(20), 1186-1187. https://doi. org/10.1136/bjsports-2020-102306

Elliott, N., Martin, R., Heron, N., Elliott, J., Grimstead, D., \& Biswas, A. (2020). Infographic. Graduated return to play guidance following COVID-19 infection. British Journal of Sports Medicine, 54(19), 1174-1175. https://doi. org/10.1136/bjs ports-2020-102637

Fabre, J.-B., Gre lot, L., Vanbiervielt, W., Mazerie, J., Manca, R., \& Martin, V. (2020). Managing the combined consequences of COVID-19 infection and lock-down policies on athletes: Narrative review and guidelines proposal for a safe return to sport. BMJ Open Sport - Exercise Medicine, 6(1). https://doi.org/10.1136/bmjsem-2020-000849

Firdaus, M. H., \& Pudjijuniarto, P. (2021). Respon Atlet Hockey Indoor Putera Jawa Timur Menghadapi Pemusatan Latihan New Normal Dalam Masa Pandemi COVID-19. Jurnal Kesehatan Olahraga,09(03), 10.

Gallego, V., Nishiura, H., Sah, R., \& Rodriguez-Morales, A. J. (2020). The COVID-19 outbreak and implications for the Tokyo 2020 Summer Olympic 
Games. Travel Medicine and Infectious Disease, 34, 101604. https://doi.org/10.1016/j.tmaid.2020.101604

Gautret, P., Al-Tawfiq, J. A., \& Hoang, V. T. (2020). COVID 19: Will the 2020 Hajj pilgrimage and Tokyo Olympic Games be cancelled? Travel Medicine and Infectious Disease, 101622. https://doi.org/10.1016/j.tmaid.2020.101622

Gunawan, A. (2020). 5 Dimensi Dampak Kebijakan COVID-19 Terhadap Sistem Keolahragaan Nasional. Jejaring Administrasi Publik, 12(1), 19.

Habeebullah, T. M., Abd El-Rahim, I. H. A., \& Morsy, E. A. (2021). Impact of outdoor and indoor meteorological conditions on the COVID-19 transmission in the western region of Saudi Arabia. Journal of Environmental Management, $\quad 288, \quad 112392$. https://doi.org/10.1016/j.jenvman.2021.112392

Halabchi, F., Ahmadinejad, Z., \& Selk-Ghaffari, M. (2020). COVID-19 Epidemic: Exercise or Not to Exercise; That is the Question! Asian Journal of Sports Medicine, 11(1). https://doi.org/10.5812/asjs m.102630

HSC Public Health Agency, H. P. H. A. (2020). COVID-19: Information for the public. https://www.publichealth. hscni.net/covid-19-coronavirus/covid-19information-public

Hughes, D., Saw, R., Perera, N. K. P., Mooney, M., Wallett, A., Cooke, J., Coatsworth, N., \& Broderick, C. (2020). The Australian Institute of Sport framework for rebooting sport in a COVID-19 environment. Journal of Science and Medicine in Sport, 23(7), 639-663. https://doi.org/10.1016/j.jsams.2020.05.004

Humas Sekretariat Kabinet Republik Indonesia, H. S. K. R. I. S. K. R. I. (2020, April 23). Pemerintah Putuskan Pelaksanaan PON ke-20 Papua Ditunda Jadi Oktober 2021. Sekretariat Kabinet Republik Indonesia. https://setkab.go.id/pemerintah-putuskan-pelaksanaan-pon-ke-20-papuaditunda-jadi-oktober-2021/

Huyghe, T., Bird, S., Calleja-González, J., \& Alcaraz, P. E. (2020). Season Suspension and Summer Extension: Unique Opportunity for Professional Team-Sport Athletes and Support Staff During and Following the COVID19 Crisis. Frontiers in Sports and Active Living, 2. https://doi.org/10.3389/fspor.2020.00098

Jagim, A. R., Luedke, J., Fitzpatrick, A., Winkelman, G., Erickson, J. L., Askow, A. T., \& Camic, C. L. (2020). The Impact of COVID-19-Related Shutdown 
24 Prayogi Dwina Angga ${ }^{1)}$, Deddy Whinata Kardiyanto ${ }^{2)}$ Jp.jok (Jurnal Pendidikan. Jasmani, Olahraga dan Kesehatan). 5(1) $11-25$

Measures on the Training Habits and Perceptions of Athletes in the United States: A Brief Research Report. Frontiers in Sports and Active Living, 2. https://doi.org/10.3389/fspor.2020.623068

Kardiyanto, D. W. (2020, Juli 26). Dampak Pandemi COVID-19 Terhadap Event Olahraga dan Sosial Ekonomi Masyarakat. Universitas Sebelas Maret. https://uns.ac.id/id/uns-opinion/da mpak-pandemi-covid-19-terhadap-eventolahraga-dan-sosial-ekonomi-masyarakat.html

Latella, C., \& Haff, G. G. (2020). Global Challenges of Being a Strength Athlete during a Pandemic: Impacts and Sports-Specific Training Considerations and Recommendations. Sports, 8(7). https://doi.org/10.3390/sports 8070100

Melchiorri, G., Ronconi, M., Triossi, T., Viero, V., De Sanctis, D., Tancredi, V., Salvati, A., Padua, E., \& Alvero Cruz, J. R. (2014). Detraining in young soccer players. The Journal of Sports Medicine and Physical Fitness, 54(1), 27-33.

Mujika, I., \& Padilla, S. (2001). Muscular characteristics of detraining in humans. Medicine and Science in Sports and Exercise, 33(8), 1297-1303. https://doi.org/10.1097/00005768-200108000-00009

Nahari, S. I., \& Faruk, M. (2021). Analis is Kondisi Fisik Atlet Putra Hoki Ruangan Jawa Timur Pada Masa Sebelum Pandemi COVID-19 dan Puslatda New Normal. Jurnal Prestasi Olahraga,4(4), 11.

Nasution, M. K. M. (2017). Modelling and Simulation of Search Engine. Journal of Physics: Conference Series, 801, 012078. https://doi.org/10.1088/17426596/801/1/012078

Noorimotlagh, Z., Jaafarzadeh, N., Martínez, S. S., \& Mirzaee, S. A. (2021). A systematic review of possible airborne transmission of the COVID-19 virus (SARS-CoV-2) in the indoor air environment. Environmental Research, 193,110612. https://doi.org/10.1016/j.envres.2020.110612

Nurfajriani, R. (2020, Oktober 18). Nasib Event Olahraga di Kala Pandemi Virus Corona, dari Ditunda hingga Dibatalkan. Pikiran-Rakyat.com. https://www.pikiran-rakyat.com/olahraga/pr-01845770/nasib-eventolahraga-di-kala-pandemi-virus-corona-dari-ditunda-hingga-dibata lkan

Own The Podium, O. T. P. (2020). COVID-19 Return to High Performance Sport Framework.pdf. Own The Podium.

Rodríguez-Fernández, A., Sánchez-Sánchez, J., Ramirez-Campillo, R., Rodríguez-Marroyo, J. A., Villa Vicente, J. G., \& Nakamura, F. Y. (2018). Effects of short-term in-season break detraining on repeated-sprint ability 
and intermittent endurance according to initial performance of soccer player. PLoS ONE, 13(8). https://doi.org/10.1371/journal.pone.0201111

Santos-Ferreira, D., Tomás, R., \& Dores, H. (2020). TEAM to Defeat COVID-19: A Management Strategy Plan to Address Return to Play in Sports Medicine. Orthopaedic Journal of Sports Medicine, 8(9). https://doi.org/10.1177/2325967120951453

Satuan Tugas Penanganan COVID-19, W. R. P. C.-19. (2020). Surat Edaran Menteri Pemuda dan Olahraga No. 6.11.1/Menpora/VI/2020. covid19.go.id. https://covid19.go.id/p/regulasi/surat-edaran-me nteri-pemuda-dan-olahragano-6111menporavi2020

Song, Y., Liu, P., Shi, X. L., Chu, Y. L., Zhang, J., Xia, J., Gao, X. Z., Qu, T., \& Wang, M. Y. (2020). SARS-CoV-2 induced diarrhoea as onset symptom in patient with COVID-19. Gut, 69(6), 1143-1144. https://doi.org/10.1136/gutjnl-2020-320891

WHO, W. (2021, November 4). Key planning recommendations for mass gatherings in the context of COVID-19. https://www.who. int/publicationsdetail-redirect/10665-332235

Wong, A. Y.-Y., Ling, S. K.-K., Louie, L. H.-T., Law, G. Y.-K., So, R. C.-H., Lee, D. C.-W., Yau, F. C.-F., \& Yung, P. S.-H. (2020). Impact of the COVID-19 pandemic on sports and exercise. Asia-Pacific Journal of Sports Medicine, Arthroscopy, Rehabilitation and Technology, 22, 39-44. https://doi.org/10.1016/j.asmart.2020.07.006

World Health Organization, W. H. O. (2020). Considerations for sports federations/sports event organizers when planning mass gatherings in the context of COVID-19. World Health Organization. https://apps.who. int/iris/bitstream/handle/10665/331764/WHO-2019-nCoVMass_Gatherings_Sports-2020.1-eng.pdf

World Health Organization, W. H. O. (2021). Coronavirus disease (COVID-19). https://www.who. int/emergencies/diseases/novel-corona virus-

2019? adgroupsurvey $=\{$ a dgroupsurve $y\}$ gc lid $=$ Cj0KCQjw6s2IBhCnARIsA P8RfAjHeHal5vSnmAbiv2QoMn8aiY-CAcgcXQ4BYAHmIAKhp7mik4Gk44aApWKEALw_wcB 